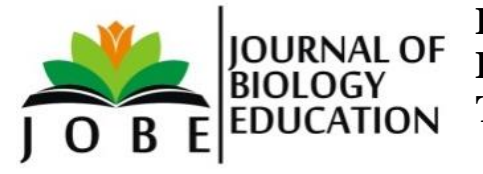

ISSN 2615-3947/P-ISSN 2615-3947

IAIN KUDUS

Tersedia online:http://journal.stainkudus.ac.id/index.php/jbe

\title{
MISCONCEPTION IN SCIENTIFIC LITERATURE ON JOURNAL ONLINE THAT DISCUSS INTEGRATION OF SCIENCE AND RELIGION IN ERA 4.0
}

\author{
1) Achmad Ali Fikri, 2) Desvi Miasari2, 3) Ika Tamara Dewi \\ 1), Tadris IPA IAIN Kudus \\ ${ }^{2), 3)}$ Tadris Biologi IAIN Kudus \\ fikri@stainkudus.ac.id
}

\begin{abstract}
ABSTRAK
Dewasa ini, seiring munculnya paradigma baru tentang integrasi sainsdan agama dalam dunia pendidikan, (yang tujuannya tidak lain adalah membekali para alumninya tidak hanya dengan kecakapan di bidang IPTEK tapi juga membekali dengan IMTAQ), bermunculan juga lah literatur-literatur ilmiah dalam hal ini adalah artikel dalam jurnal ilmiah yang mengangkat topik atau tema tentang integrasi sains dan agama. Artikel-artikel tersebut disusun oleh para penulis dari berbagai jenis latar belakang pendidikan yang berbeda yang tentunya berbeda pula pemahamannya atas konsep atau materi sains itu sendiri.Penelitian ini bertujuan untuk mengungkap sekaligus memberi pencerahan atas adanya miskonsepsi dalam literatur ilmiah yang mengkaji integrasi sains dan Agama (Islam).Penelitian ini merupakan penelitian kualitatif dengan metode studi kasus, proses pengumpulan data dilakukan dengan cara mengumpulkan dan mendokumentasikan artikelartikel ilmiah yang mengkaji integrasi sains dan Agama pada jurnal ilmiah dari berbagai perguruan tinggi di Indonesia.Data yang terkumpul kemudian diananlisis dengan theorical analysis. Hasil penelitian menunjukkan bahwa banyak miskonsepsi dalam literatur ilmiah yang mengkaji integrasi sains dan Agama (Islam)yaitu kaitannya dengan konsep sains yang dijabarkan. Harapannya, dengan hasil penelitian ini dapat mengetuk hati para peneliti ataupun akademisi dengan latar belakang pendidikan di bidang sains untuk meningkatkan dan mengembangkan penelitian-penelitian terkait integrasi sains dan agama (Islam).
\end{abstract}

Kata kunci :Miskonsepsi, Integrasi, Sains, Agama

\begin{abstract}
Today, as the emergence of a new paradigm of integration of science and religion in education, (whose purpose is none other than equip its graduates not only with skills in the field of science and technology but also equip with IMTAQ), sprung also was the literature of science in this case is articles in scientific journals that raise topics or themes about the integration of science and religion. The articles were composed by writers of various types of different educational backgrounds, which of course differed in their understanding of the concept or material of
\end{abstract}


science itself. This study aims to uncover as well as provide enlightenment on the misconceptions in the scientific literature that examine the integration of science and religion (Islam). This research is a qualitative research with case study method, the data collection process is carried out by collecting and documenting scientific articles that examine the integration of science and religion in scientific journals from various universities in Indonesia. The collected data is analyzed by theorical analysis. The results of the study show that many misconceptions in the scientific literature are examining the integration of science and religion (Islam), which is related to the concept of science described. The hope, with the results of this study can tap the hearts of researchers or academics with educational backgrounds in the field of science to improve and develop research related to the integration of science and religion (Islam).

Keywords: Misconception, Integration, Science, Religion

\section{PENDAHULUAN}

Salah satu sifat ilmu pengetahuan adalah dinamis dan selalu berkembang. Perkembangan ilmu pengetahuan ini tidak lain adalah karena adanya penemuanpenemuan baru ataupun paradigma-paradigma baru yang dikemukakan oleh para ilmuwan dalam bidang ilmu itu sendiri(semua ilmu secara umum) Di dalam ilmu, sebenarnya tidak ada pemisahan satu dengan yang lainnya, melainkan spesialisasispesialisasi yang berjalan secara kompetitif dan saling memberikan manfaat dalam semua aspek kehidupan manusia(Purwaningrum, 2015).

Ilmu pengetahuan erat kaitannya dengan proses Pendidikan. Melalui pendidikan ilmu pengetahuan tidak hanya ditransferkan begitu saja, akan tetapi lebih dari itu dilengkapi dengan muatan nilai, sikap dan karakter. Di Indonesia, Pendidikan tidak hanya menjadi tanggung jawab pemerintah, tetapi juga tanggung jawab keluarga dan masyarakat. Pemerintah dalam mengaplikasikan Pendidikan dalam hal ini adalah Pendidikan nasional diatur oleh Undang-Undang Nomor 20 Tahun 2003 tentang Sistem Pendidikan Nasional.

Salah satu tujuan pendidikan nasional yang termaktub dalam UndangUndang Nomor 20 Tahun 2003 tentang Sistem Pendidikan Nasional adalah berkembangnya potensi peserta didik agar menjadi manusia yang beriman dan bertakwa kepada Tuhan Yang Maha Esa, berakhlak mulia, sehat, berilmu, cakap, kreatif, mandiri, dan menjadi warga negara yang demokratis serta bertanggung jawab(Presiden Republik Indonesia, 2003). Dari tujuan tersebut dapat ditarik 
kesimpulan bahwa hasil akhir Pendidikan adalah tidak hanya ilmu pengetahuan dan teknologi (IPTEK), akan tetapi juga iman dan takwa (IMTAK). Seiring dengan hal tersebut, dewasa ini dalam dunia Pendidikan kita di Indonesia muncul paradigma baru tentang integrasi sains dan agama (Islam). Integrasi ini salah satunya dilakukan dengan cara mengkaitkan atau merujuk bidang kajian, konsep dan materi-materi sains dengan dalil-dalil naqli baik dari ayat-ayat Al-Quran maupun dari Al-Hadits.

Munculnya paradigma baru ini berimplikasijuga pada dunia penelitian dan literatur ilmiah (jurnal), banyak artikel atau penelitian-penilitian yang mengangkat topik tentang integrasi sains dan agama ini. Dari banyak artikel tersebut, sebagian besar ditulis oleh para penulis dari berbagai latar belakang pendidikan yang berbeda-beda bahkan tidak sedikit yang latar belakangnya di luar bidang sains.

Perbedaan latar belakang Pendidikan penulis tentunya mempengaruhi tingkat pemahaman dan penguasaan konsep sains dari para penulisnya sendiri. Secara lebih jauh pastinya berpengaruh terhadap jabaran hasil penulisannya khususnya tentang konsep sains yang dikemukakan, bahkan lebih luas lagi dapat mempengaruhi para pembaca dari artikel tersebut terlebut terlebih jika dibaca para siswa dengan rasa ingin tahu yang tinggi, yaitu salahsatusikapyang harus dikembangkan dalam sains itu sendiri (Ali Fikri, 2015).Sebagai contoh adalah munculnya miskonsepsi dalam artikel tentang integrasi sains dan agama, yang jika dibaca oleh para siswa tentunya akan mempengaruhi pemahaman maupun penerimaan konsepnya, sehingga dengan penelitian ini penulis bertujuan untuk mengungkap sekaligus memberi pencerahan atas adanya miskonsepsi dalam literatur ilmiah yang mengkaji integrasi sains dan Agama (Islam).

Paradigma baru ini juga menepis adanya dikotomi ilmu pengetahuan. Selama ini, ada semacam dikotomi atau pemisahan yang demarkatis antara ilmu Islam dan ilmu mainstream (umum/Barat). Dan, hal ini berimplementasi bahwa umat Islam itu seakan dilarang atau tabu ketika belajar tentang ilmu-ilmu umum tadi. Yang terjadi kemudian, ada semacam alergi terhadap ilmu-ilmu tersebut, yang faktanya sangat dibutuhkan oleh umat manusia(Mustaqim, 2015). 
Dikotomi ilmu ke dalam ilmu agama dan non agama sebenarnya bukan hal baru. Islam telah memiliki tradisi dikotomi ini sejak dulu, seperti Al-Ghazali menyebut kedua jenis ilmu tersebut sebagai ilm syar'iyah dan ghairu syar'iyah, tetapi dikotomi tersebut tidak banyak menimbulkan problem dalam sistem pendidikan Islam, hingga sistem pendidikan barat diperkenalkan ke dalam Islam melalui imperealisme. Sejak itulah tejadi dikotomi yang sangat ketat antara ilmuilmu umum (yang nantinya bisa disebut dengan ilmu sekuler) dan ilmu-imu agama(Rijal, n.d.).

Dengan adanya usaha integrase atau Islamisasi pengetahuan diharapkan dapat mengspritualisasikan atau pemberian nilai-nilai rohaniah padaupaya penggalian dan pengamalan ilmu pengetahuan, sehinggamelahirkan ilmu pengetahuan yang utuh dan tidak mengalami dikotomi(Samrin, 2013).Integrasi atau Islamisasi ilmu pengetahuan ini merupakan salah satu bentuk kreativitas dalam mengembangkan ilmu pengetahuan. Kreativitas atau berfikir kreatif harus dipupuk sejak dini karena dapat meningkatkan kemampuan untuk melihat bermacam-macam kemungkinan penyelesaian terhadap suatu masalah(Ali Fikri, 2018). Integrasi atau Islamisasi ilmu pengetahuan diharapkan mampu menjadi paradigma dalam menghadirkan kejayaan ilmu-ilmu Islam "yang sebenarnya" sebagaimana yang telah digagas oleh para cendekiawan Muslim abad permulaan dan pertengahan(Mustaqim, 2015).

\section{METODE PENELITIAN}

Penelitian ini merupakan penelitian kualitatifyaitu penelitian yang digunakan untuk meneliti pada kondisi objek yang alamiah. Karena dilakukan pada objek yang alamiah maka penelitian kualitati sering disebut juga dengan penelitian naturalistik(Sugiyono, 2012). Diantara ciri-ciri penelitian ini adalah verifikasi yaitu melalui kasus yang bertentangan atau negative. Selain itu penelitian kualitatif ini dalam hal pengambilan sample dilakukan secara purposif yaitu sedikit dan dipilih menurut tujuan penelitian(Saiful Rahmat, 2009).

Penelitian ini menggunakanpendekatan ataupun metode studi kasus yaitu sebuah eksplorasi dari suatu kasus atau beragam kasus melalui pengumpulan data yang mendalam serta melibatkan berbagai sumber informasi dalam suatu konteks. 
Sistem terikat ini diikat oleh waktu dan tempat sedangkan kasus dapat dikaji dari suatu program, peristiwa, aktivitas atau suatu individu. Dengan kata lain, studi kasus merupakan penelitian dimana peneliti menggali suatu fenomena tertentu (kasus) dalam suatu waktu dan kegiatan serta mengumpulkan informasi secara terinci dan mendalam dengan menggunakan berbagai prosedur pengumpulan data(Kusmarni, n.d.).

Datapada penelitian ini adalah artikel-artikel ilmiah yang mengkaji integrasi sains dan Agama khususnya sains yang berkaitan dengan konsep biologi. Sampel penelitian ini adalah tiga artikel ilmiah yang diambil secara purposive dari populasi artikel-artikel ilmiah yang mengkaji integrasi sains dan Agama pada jurnal ilmiah dari berbagai perguruan tinggi di Indonesia. Proses pengumpulan data pada penelitian ini dilakukan dengan cara mengumpulkan dan mendokumentasikan artikel-artikel ilmiah yang mengkaji integrasi sains dan Agama. Data yang terkumpul kemudian diananlisis dengan theorical analysis.Kemudian hasil penelitian disusun secara naratifberdasarkan konsep dan teori biologi, yaitu sebagai jawaban atas miskonsepsi yang di temukan dari beberapa artikel ilmiah.

\section{HASIL DAN PEMBAHASAN}

Miskonsepsi adalah kegagalan atau kesalahan dalam memahami atau menjabarkan suatu konsep tertentu. Fowler dan Jaoude (1987) menyatakan bahwa yang dimaksud dengan miskonsepsi adalah pengertian tentang suatu konsep yang tidak tepat, salah dalam menggunakan konsep nama, salah dalam mengklasifikasikan contoh-contoh konsep, keraguan terhadap konsep-konsep yang berbeda, tidak tepat dalam menghubungkan berbagai macam konsep dalam susunan hierarkinya atau pembuatan generalisasi suatu konsep yang berlebihan atau kurang jelas(Laksana, 2016). Dalam penelitian ini miskonsepsi yang dimaksud adalah miskonsepsi biologi, sehingga dapat disimpulkan bahwa miskonsepsi biologi adalah kegagalan atau kesalahan dalam memahami atau menjabarkan tentang suatu konsep dalam biologi.

Miskonsepsi dapat terjadi karena pemberian informasi atau konsep yang kurang tepat, atau dapat juga terjadi karena kurang tepatnya seseorang dalam 
menangkap informasi atau konsep yang diberikan. Hal tersebut tersebut sangat mungkin terjadi jika informasi atau konsep tersebut di dapat dari suatu sumber atau referensi bacaan saja tanpa adanya tatap muka, diskusi ataupun forum ilmiah yang membahas tentang informasi atau konsep tersebut. Miskonsepsi juga dapat terjadi jika orang yang menangkap suatu informasi atau konsep tidak memiliki latar belakang ataupun Pendidikan yang relevan dengan konsep tersebut sehingga sangat memungkinkan kurang tepat dalam menangkap atau memahami suatu konsep khususnya biologi dalam penelitian ini. Amien (1990) miskonsepsi dapat pula terjadi karena adanya gagasan atau ide yang didasarkan pada pengalaman yang tidak relevan (Laksana, 2016).

Dari tiga sampel yang diambil dalam penelitian ini, yaitu dari artikel ilmiah yang mengkaji integrasi sains dan agama, terjadinya miskonsepsi biologi adalah disebabkan karena ketiga penulis memiliki latar belakang Pendidikan di luar biologi atau dengan kata sederhananya adalah bukan merupakan orang biologi. Hal ini sesuai dengan keterangan sebelumnya bahwasanya miskonsepsi dapat pula terjadi karena latar belakang yang tidak relevan.

Dari ketiga sampel juga diketahui bahwa miskonsepsi yang muncul terletak pada penjelasan suatu konsep yang tidak tepat, salah dalam menggunakan atau menjelaskan konsep nama atau definisi, dan tidak tepat dalam pembuatan generalisasi suatu konsep yang berlebihan atau kurang jelas. Miskonsepsi yang muncul dalam sampel penelitian iniselain muncul dalam penjabaran suatu konsep dengan kalimatatau konsep yang kurang tepat(1 sampel) maupun juga kesalahan dalam memberikan penjelasan dari suatu konsep dengan menggunakan tanda kurung(2 sampel) .

Tanda kurung sendiri menurut Pedoman Umum Ejaan Bahasa Indonesia(PUEBI) yang disempurnakan memiliki beberapa fungsi diantaranya adalah untuk mengapit tambahan keterangan atau penjelasan, untuk mengapit keterangan atau penjelasan yang bukan bagian utama kalimat, untuk mengapit huruf atau kata yang kehadirannya di dalam teks dapat dihilangkan dan untuk mengapit angka atau huruf yang memerinci urutan keterangan(Tim Pengembang Pedoman Bahasa Indonesia, 2016). 
Miskonsepsidalam artikel-artikel ilmiah yang mengkaji integrasi sains dan Agama ditemukan penulis padatiga sampel artikel khususnya sains yang berkaitan dengan konsep biologi. Pada artikel pertamapenulis menemukan miskonsepsi yaitu dalam penjabaran suatu konsep dengan kalimat atau konsep yang kurang tepat. Miskonsepsi tersebut seperti yang terlihat dalam gambar 1. berikut ini ;

\section{cooper atau mery. Sedangkan kelenjar lettre mengeluarkan semacam lendir yang licin. ${ }^{13}$ \\ Di dalam sel sperma terdapat kurang lebih 26 juta sel, kepalanya agak gepeng dan ekornya agak panjang. Ketika sel ini masuk pada rahim, maka terjadilah pembuahan (fecundation), suatu persenyawaan antara sperma dan ovum. Pembuahan yang mendatangkan kehamilan terjadi karena sel telur dibuahi oleh sel-sel yang sangat kecil sekali, yang panjangnya kurang lebih_0,0001 mm. Dari jutaan sel-sel yang keluar dari pria normal hanya satu saja yang mampu membuahi. Sel-sel yang tidak berhasil menerobos dari jalan mulut vagina melalui terowongan menuju ke rahim akan mati. ${ }^{14}$ \\ Begitu turun ke rahim (uterus) melalui tabung fallopi, pada saat itulah, ia telah mulai terpecah, kemudian menanamkan dirinya dengan menyusup ke dalam ketebalan atau kekentalan lender dan otot-otot tatkala tembuni mulai terbentuk. ${ }^{15}$ Sperma yang membuai sel telur (ovum) kemudian turun ke rahim dijelaskan Allah dalam QS al- Mu'minûn [23]: 13; Thumm ja'alnâh nutfah fí qarar makìn (Kemudian Kami iadikan sarinati itu air mani (vang disimnan) dalam temnat vano kokoh}

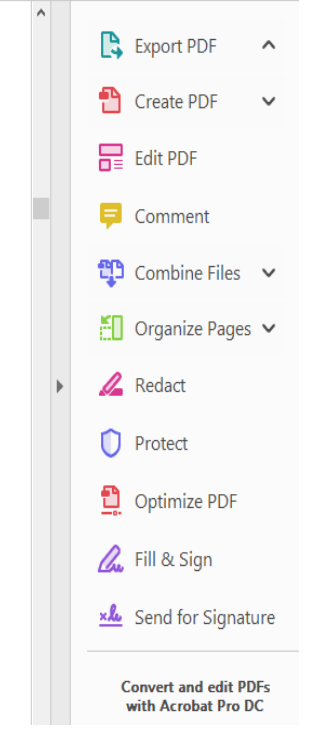

Gambar 1. Miskonsepsi pada sampel artikel 1.

Berdasarkan gambar 1. penulis artikel tersebut menjabarkan bahwa '’Di dalam sel sperma terdapat kurang lebih 26 juta sel, kepalanya agak gepeng dan ekornya agak panjang. Ketika sel ini masuk pada rahim, maka terjadilah pembuahan (fecundation)',. Jika kita perhatikan artikel tersebut, sama halnya penulis artikel mengemukakan bahwa terdapat sel di dalam sel. Haltersebut jelas bertentangan dengan konsep biologi yang berkaitan dengan konsep sel.

Dalam konsep biologi, Sel adalah unit terkecil dari kehidupan, yang memiliki bentuk dan ukuran yang berbeda-beda tergantung tempat dan fungsi dari jaringan yang disusunnya.Sel pertama kali yang ditemukan oleh Robert Hooke pada tahun 1665. Faktatentang sel semakin berkembang dengan digunakannyaScanning Electron Mycroscope (SEM) yang lebih jelas untuk dapat melihat topografi sel.

Sel adalah suatu wadah yang di dalamnya terjadi aktivitas biosintesis ribuan molekul yangsangat dibutuhkan untuk kehidupan organisme yang memiliki sel tersebut(Nurhayati \& Darmawati, 2017). Dari uraian di atas dapat disimpulkan 
bahwa sel merupakan unit terkecil dari kehidupan, tidak ada sel di dalam sel, yang ada adalah organel dan molekul kimia yang dibutuhkan sel tersebut.

Miskonsepsi yang lain penulis temukan pada artikel ke dua, yaitu penulis menemukan miskonsepsi dalam memberikan penjelasan dari suatu konsep dengan menggunakan tanda kurung. Miskonsepsi tersebut seperti yang terlihat dalam gambar 2. berikut ini ;

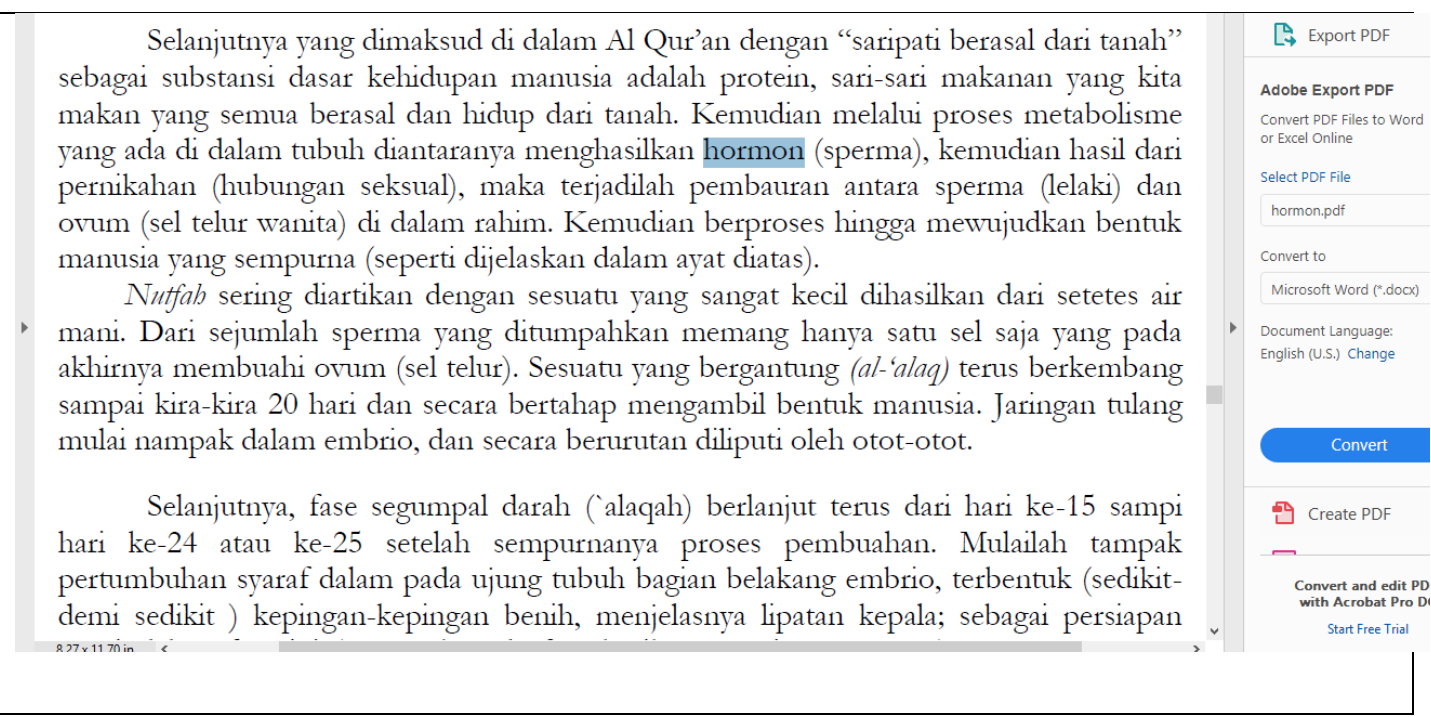

Gambar 2. Miskonsepsi pada sampel artikel 2.

Berdasarkan gambar 2. penulis artikel tersebut mengemukakanbahwa "proses metabolisme yang ada di dalam tubuh diantaranya menghasilkanhormon (sperma)'. Kalau kita melihat kembali fungsi tanda kurung dalam Pedoman Umum Ejaan Bahasa Indonesia (PUEBI), salah satunya adalah untuk mengapit tambahan keterangan atau penjelasan, sehingga jika kita terapkan pada artikel dua diatas maka sama halnya dengan bahwa sperma adalah penjelasan dari hormon atau dengan kata lain hormon sama dengan sperma.Hal tersebut jelas bertentangan dengan konsep biologi yang berkaitan dengan konsep sperma.

Dalam konsep biologi, sperma merupakan salah satu jenis sel,penyebutan sperma merupakan singkatan dari spermatozoa.Pembentukan sel spermatozoa (tunggal : spermatozoon) terjadi di organ kelamin (gonad) jantan yaitu testis tepatnya di tubulus seminiferus. Sel spermatozoabersifat haploid (n) dibentuk di dalam testis melewati sebuah proses kompleks(Sukada, n.d.). Proses pembentukan spermatozoa atau dalam biologi disebut dengan spermatogenesis dipengaruhi oleh kerja beberapa hormon, diantaranyaadalah Folicle Stimulating Hormon(FSH), hormon lutein atau Luteinizing Hormon(LH), hormon testosteron dan hormon 
pertumbuhan. Jadi jelas bahwa spermatozoa adalah sel bukannya hormone, justru dalam pembentukan sel sperma tersebut membutuhkan beberapa hormone tertentu.

Pada artikel ke tiga, penulis menemukan miskonsepsi seperti halnya pada artikel ke dua yaitu miskonsepsi dalam memberikan penjelasan dari suatu konsep dengan menggunakan tanda kurung. Miskonsepsi tersebut seperti yang terlihat dalam gambar 3. berikut ini ;

\begin{tabular}{|c|c|c|c|}
\hline & 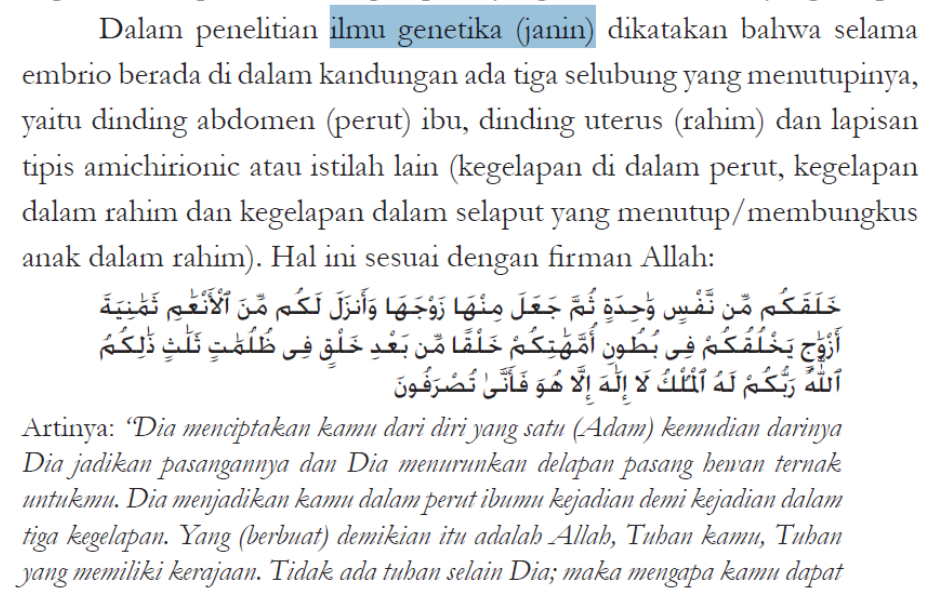 & $\bar{n}$ & 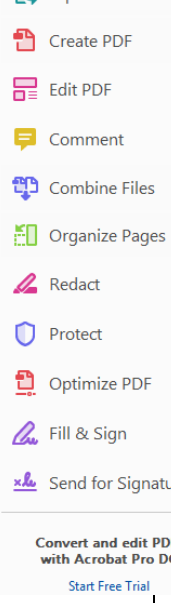 \\
\hline
\end{tabular}

Gambar 3. Miskonsepsi pada sampel artikel 3.

Berdasarkan gambar 3. penulis artikel tersebut mengemukakan bahwa "'ilmu genetika (janin)". Kalau kita melihat kembali fungsi tanda kurung dalam Pedoman Umum Ejaan Bahasa Indonesia (PUEBI), salah satunya adalah untuk mengapit tambahan keterangan atau penjelasan, sehingga jika kita terapkan pada artikel ke tiga diatas maka sama halnya dengan bahwa janin adalah penjelasan dari ilmu genetika atau dengan kata lain ilmu genetika sama dengan janin atau ilmu janin. Hal tersebut jelas bertentangan dengan konsep biologi yang berkaitan dengan konsep genetika.

Dalam konsep biologi, genetika merupakan salah satu bagian atau cabang dari biologi. Genetika merupakan cabang ilmu dari biologi yang mencoba menjelaskan persamaan dan perbedaan sifat yang diturunkan pada makhluk hidup. Selain itu, genetika juga mencoba menjawab pertanyaan yang berhubungan dengan apa yang diturunkan atau diwariskan dari induk kepada turunannya, bagaimana mekanisme materi genetika itu diturunkan, dan bagaimana peran materi genetika tersebut(Wirjosoemarto, n.d.). 
Demikian pemaparan terkait beberapa miskonsepsi dalam artikel-artikel ilmiah yang mengkaji integrasi sains dan Agama khususnya sains yang berkaitan dengan konsep biologi. Sebagai bagian dari dunia keilmuan, penulis yang memiliki latar belakang dari Pendidikan biologi merasa memiliki tanggung jawab untuk mengungkap dan memberikan pencerahan terhadap miskonsepsi yang muncul dalam artikel ilmiah yang mengkaji integrasi sains dan Agama tersebut. Besar harapan penulis agar dapat mengetuk hati para peneliti ataupun akademisi dengan latar belakang pendidikan di bidang sains khususnya biologi untuk meningkatkan dan mengembangkan penelitian-penelitian terkait integrasi sains dan agama (Islam).

\section{SIMPULAN}

Terjadinya miskonsepsi biologi pada artikel ilmiah yang mengkaji integrasi sains dan agamaadalah disebabkan karena penulis artikel tersebut memiliki latar belakang Pendidikan di luar biologi atau dengan kata sederhananya adalah bukan merupakan orang biologi. Miskonsepsi muncul karenapenjelasan suatu konsep yang tidak tepat, salah dalam menggunakan atau menjelaskan konsep nama atau definisi, dan tidak tepat dalam pembuatan generalisasi suatu konsep yang berlebihan atau kurang jelas.

Para peneliti ataupun akademisi dengan latar belakang pendidikan di bidang sains khususnya biologi hendaknya dapat meningkatkan dan mengembangkan penelitian-penelitian terkait integrasi sains dan agama (Islam). Para peneliti yang hendak meneliti atau menulis artikel tentang integrasi sains dan agama (Islam) hendaknya juga melakukan kolaborasi dengan para peneliti yang memiliki latar belakang Pendidikan yang relevan. 


\section{DAFTAR PUSTAKA}

Ali Fikri, A. (2015). Pengembangan Perangkat Pembelajaran Biologi Dengan Model Guided Inquiry Untuk Meningkatkan Rasa Ingin Tahu Dan Creative Thinking Siswa SMA Negeri 2 Bantul Pada Materi Ekosistem.

Ali Fikri, A. (2018). Pengembangan Perangkat Pembelajaran Model Guided Inquiry Untuk Meningkatkan Creative Thinking Siswa. Thabiea, 1(1).

Kusmarni, Y. (n.d.). Studi Kasus.

Laksana, D. N. L. (2016). Miskonsepsi Dalam Materi IPA Sekolah Dasar. Jurnal Pendidikan Indonesia, 5(2), 873-882.

Mustaqim, M. (2015). Pengilmuan Islam dan Problem Dikotomi Pendidikan. Jurnal Penelitian, 9(2), 255-274.

Nurhayati, B., \& Darmawati, S. (2017). Biologi Sel dan Molekuler.

Presiden Republik Indonesia. Undang-undang sistem pendidikan nasional (2003). Purwaningrum, S. (2015). Elaborasi Ayat-Ayat Sains dalam Al-Quran : Langkah Menuju Integrasi Agama dan Sains dalam Pendidikan. Inovatif, 1(1), 124141.

Rijal, S. (n.d.). Integrasi Keilmuan Umum Dan Agama.

Saiful Rahmat, P. (2009). Penelitian Kualitatif. Equilibrium, 5(9), 1-8.

Samrin. (2013). Dikotomi Ilmu Dan Dualisme Pendidikan. Jurnal Al-Ta'dib, 6(1), 189-198.

Sugiyono. (2012). Metode Penelitian Kuantitatif Kualitatif dan $R \& D$. Bandung: Alfabeta.

Sukada, I. K. (n.d.). Gametogenesis oogenesis spermatogenesis.

Tim Pengembang Pedoman Bahasa Indonesia. (2016). Pedoman Umum Ejaan Bahasa Indonesia.

Wirjosoemarto, K. (n.d.). Hukum Mendel dan Pewarisan Sifat. 